\title{
The Synthesis of Cinchonine Tiglat Ester Compound and Cytotoxic Test Against MCF-7 Breast Cancer Cell
}

\author{
Ahmad Khanifudin ${ }^{1}$, Gian Primahana ${ }^{2}$, Sylvia Rizky Prima ${ }^{1}$, Puspa D. Lotulung ${ }^{2}$, and Muhammad \\ Hanafi $^{2 *}$ \\ ${ }^{1}$ Faculty of Pharmacy, University of 17 Agustus 1945, North Jakarta, Indonesia \\ ${ }^{2}$ Research Center for Chemistry, Indonesian Institute of Sciences, Kawasan Puspiptek, Serpong, Indonesia \\ *Corresponding author: hanafi124@gmail.com
}

\begin{tabular}{|c|}
\hline$A R T I C L E$ INFO \\
\hline Article history: \\
\hline Received date :23 May 2017 \\
\hline Revised date : 29 May 2017 \\
\hline Accepted date:13 June 2017 \\
\hline $\begin{array}{l}\text { Available online at : } \\
\text { http://inajac.lipi.go.id }\end{array}$ \\
\hline $\begin{array}{l}\text { Keywords: } \\
\text { cinchonine, cinchonine tiglat, } M C F- \\
7 \text { breast cancer cell }\end{array}$ \\
\hline
\end{tabular}

\section{INTRODUCTION}

Cancer is one of the main cause of death in developing Countries. GLOBOCAN estimated that by 2012, there were 14,1 million cases of newfound cancer and approximately 8,2 million deaths with relation to cancer in the whole world; with lung cancer and breast cancer being two of the most prominently diagnosed and suspected cause of death [1]. With 1,7 million cases and 521.900 deaths bay 2012 , breast cancer is the most prevalent type of cancer which is found in women. Approximately $25 \%$ of all cancer cases and $15 \%$ of cancer induced deaths are attributed to breast cancer. Developed countries accounted $50 \%$ of breast cancer cases and $38 \%$ of death caused by breast cancer [2].

Quinine and its derivatives were found to contain potential anticancer agents. Quinine has been known for its benefits as antimalarial agent [3]; but more recent studies found that it contains chincona alkaloid derivatives with anticancerous properties against leukemia or white blood cell cancer (K562/ADM), mouth cancer (KB and Hep-2), breast cancer (MCF7), liver cancer (HepG2), lung cancer colon cancer, and neuroblastoma (SH-SY5Y) $[4,5,6]$. One of the quinine derivative has even been clinically tested for (phase-III) pancreatic cancer chemotherapy agent [3].

Chincona's alkaloid compound consist of two primary rings; the quinoline ring and the quinuclidine ring (Figure 1). The quinoline ring has anticancerous, anti malarial, and anti inflammatory properties $[7,8]$. Compounds with quinoline ring affect parasites in their schizoints phase and eject them from the blood stream [9]. Quinine and its derivatives have autophagic effect; the breaking down of intracellular components by lysosome [10]. This autophagic ability causes the compounds' cytotoxicity. Quinacrine's (a derivative of quinine) autophagic ability is able to cause death to cancer cell by increasing $p 53$ and $p 21$ [11]. 


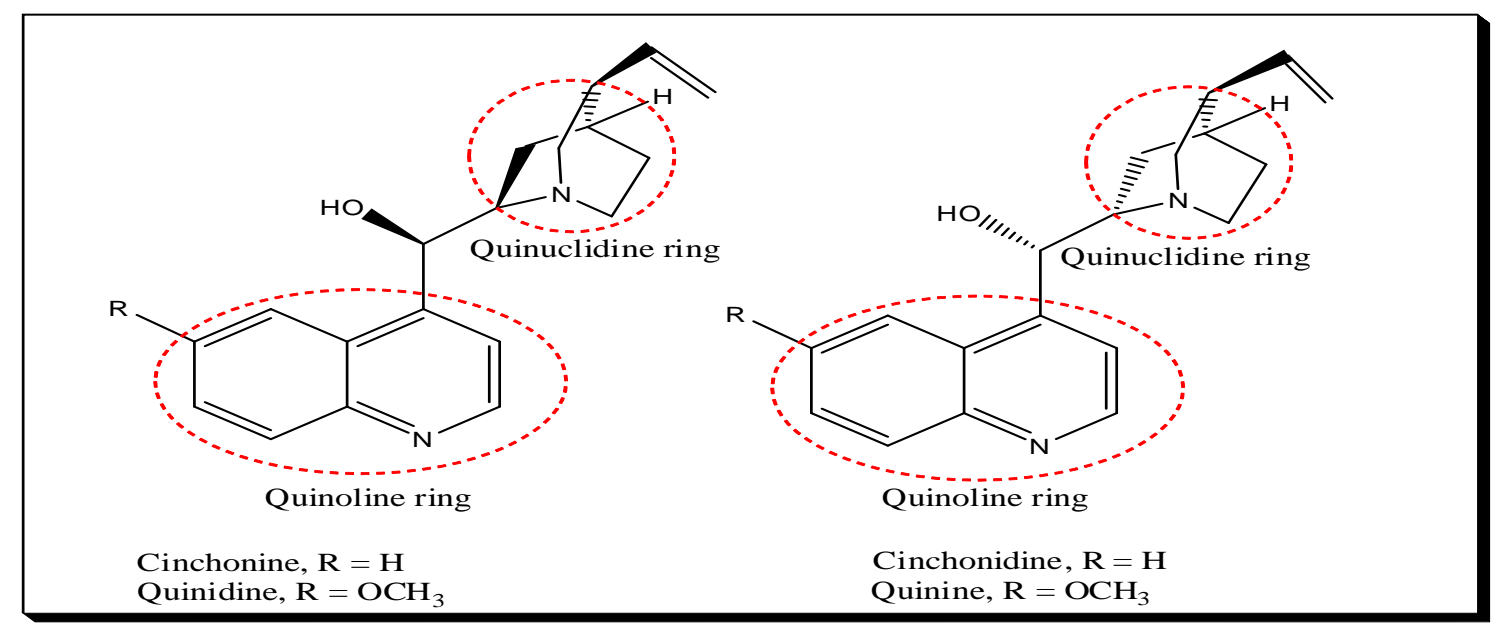

Fig. 1. Cinchona alkaloid and their basic skeleton

Cinchonine is one of the chincona alkaloids which has anticancer properties. An in vitro study conducted by Genne et al concluded that cinchonine goes against leukemic cell K562/ADM; with maximum effect being achieved at $5 \mu \mathrm{M}$; better than quinine which is known to achieve its maximum potential at 10 $\mu \mathrm{M}$. When introduced to plasma, cinchonine's bond with protein is not as strong as that of quinine's. Cinchonine has $37-55 \%$ of free phase while quinine has $20-30 \%$. This makes cinchonine more active than quinine [12]. When cinchonine is combined with Doxorubicine, it is very active against leukemic cell in rats P388/DOX [13]. Cinchonine shows activity against MES-SA uterine sarcoma [14]. Cinchonine is known to be more active compared to other cinchonian alkaloids against colon cancer's cells in rats (DHD/K12/Prob) and human leukemic cells (K562/ADM). Cinchonine also has much lower toxicity compared to other cinchonian alkaloids [15].

Cinchonine is a hematologic anti-multidrug resistance (MDR) agent for its tolerance and its ability to remain in serum. Cinchonine is also a more efficient in vitro, ex vivo, and in vivo anti-MDR agent when compared to quinine when administered with parenteral route. Cinchonine inhibits the function of $\mathrm{P}$ glycoprotein as drugs' reflux pump on cancer cells [16]. Multiple drug resistances (MDR) is the prime cause of failure in cancer chemotherapies [17].
In this study, a cinchonine ester is synthesized, which will be mixed with tiglic acid through esterification. Ester is a prodrug that can easily be hydrolized to facilitate its distribution [18]. Cinchonine has only one hydroxyl group, hence why its esterification is relatively easy to achieve [19]. The combination of cinchonine and tiglic acid is expected to be an effective and efficient chemotherapy agent; by increasing its lipophilicity, its activity will increase [20].

\section{EXPERIMENTAL SECTION}

\subsection{Materials and Instrument}

Three neck Rounded Flask, Liebig Condenser, Magnetic stirrer (IKA-C MAG HS7), Chromatography Column, Spektrofotometer NMR (JEOL JNM ECA500), Spektrofotometer LC-MS (Marinier Biospectrometry), incubator CO2, ELISA (Enzyme Linked Immunosorbent Assay) plate reader, hemocytometer, conical tube sterile, scapper, 96 well plate, micropipette and tissue culture flask.

Cinchonine obtained from Local supplier (PT. Sinkona Indonesia Lestari - Indonesia), tiglic acid p.a (Merck), Ethyl acetate p.a (Merck), Chloroform p.a (Merck), Dichloromethane p.a (Merck), ethanol p.a (Merck), n-heksan p.a (Merck), N, N-4dicyclohexylcarbodiimide (DCC, Sigma D3128 p.a.), Dimethylaminopyridine (DMAP, Sigma D5640 p.a.), thin layer chromatography (KLT, Merck GF254 0,25 mm), Silica gel 60, 
Medium culture DMEM (Dulbecco's Modified Eagle's Medium, Merck), Phospat Buffer Saline (PBS, Gibco), Trypsin EDTA 0,25\% (Gibco, Invitrogen, Canada) dan Alamar Blue (Serotec Limited).

\subsection{Methods}

\subsubsection{Synthesis of cinchonine tiglat}

As much as $588,78 \mathrm{mg}(2,0 \mathrm{mmol})$ of cinchonine was dissolved with dichloromethane as the solvent; then 240,05 $\mathrm{mg}(2,4 \mathrm{mmol})$ of tiglic acid and $495,19 \mathrm{mg}$ $(2,4 \mathrm{mmol})$ of $\mathrm{N}, \mathrm{N}$-dicyclohexylcarbodiimide (DCC) activator were added. The mixture was then stirred using magnetic stirrer for 1 hour. After an hour had passed, N,Ndimethylaminopyrine (DMAP 20\%) was then added to the mixture as a catalyst. The mixture was then stirred with constant speed for 24 hours [21]. The resulting product was indentified using thin layer chromatography. The purification of cinchonincinnamate was done with column chromatography using 7:3 mixture of ethyl acetate and chloroform respectively as solvent.

\subsubsection{Preparation of cancer cell lines}

The cancer cell used in this study was from breast carcinoma Michigan Cancer Foundation (MCF-7). The cells were grown in Dulbecco's Modified Eagle Media (DMEM) culture media with 10\% Fetal Bovine Serum (FBS). The cells were cultured inside a tissue culture dish and were incubated at a constant temperature and humidity of $37^{\circ} \mathrm{C}$ and $5 \%$ respectively for 3 days until culture growth of $60-70 \%$ was achieved. The media were then renewed with fresh plate and reincubated for another 24 hours. The media were then eliminated and the cultures were rinsed using Phosphate Buffer Saline (PBS) for 1-2 times. A $0,25 \%$ tripsinEDTA solution was added to release the culture from the plate's wall. The cells' suspensions were then moved to sterile conical tubes containing new media.
The testing was conducted using Alamar Blue method. The standard solution was created by dissolving $1 \mathrm{mg}$ of sample into 1 $\mathrm{mL}$ of DMSO. It was then diluted serially to concentrations of $20 \mathrm{ppmp} ; 10 \mathrm{ppm} ; 5 \mathrm{ppm}$; 2,5 ppm; $1,25 \mathrm{ppm} ; 0,625 \mathrm{ppm} ; 0,3125 \mathrm{ppm}$; $0,1563 \mathrm{ppm} ; 0,0781 \mathrm{ppm}$, and 0,0391 ppm. Ten $\mu \mathrm{L}$ of sample solutions (with varying concentrations) were added to every $100 \mu \mathrm{L}$ of cancer cells; distributed into 96 well plates; and incubated for 24 hours at $37^{\circ} \mathrm{C}$. The colouring process was done by adding Alamar Blue solution for 4 hours. The cell's spectral intensity was quantified using ELISA plate reader on $560 \mathrm{~nm}$ excitation wavelength and $590 \mathrm{~nm}$ of emission wavelength [22]. The viability percentage was calculated based on the following formula:

$$
\frac{O D(\text { cell }+ \text { sample })-O D(\text { negative control })}{O D(\text { cells })-O D(\text { negative controls })} \times 100
$$

The $\mathrm{IC}_{50}$ value was analyzed using linear regression between the percentage of living cells and the logarithm of sample's concentration.

\section{RESULTS AND DISCUSSION}

\subsection{Synthesis of cinchonine tiglat}

The cinchonine tiglat was successfully synthesized with the help of DCC activator as well as the DMAP catalyst in dichloromethane (Figure 2). The reaction took 24 hours to finish at room temperature and pressure inside a round-bottom flask while being constantly stirred. The combination of activator and catalyst's usage was expected to increase the product's yield and decrease the temperature and energy needed to fuel the reaction. The aforementioned reaction yielded 25,28\% product; with the resulting product has an oily characteristic. The obtained yield was still relatively low; so optimizing the reaction by re-adjusting the temperature is recommended.

\subsubsection{In vitro anticancer activity}



pp. 54-61, December 2017

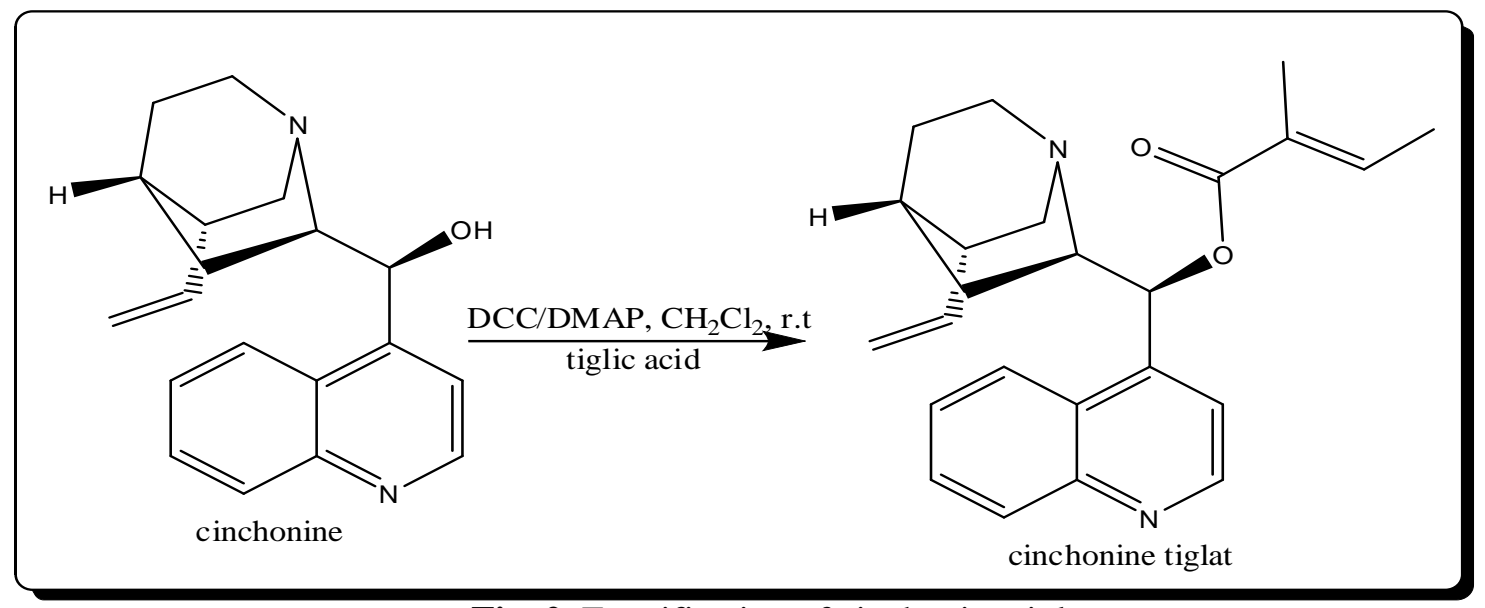

Fig. 2. Esterification of cinchonine tiglat

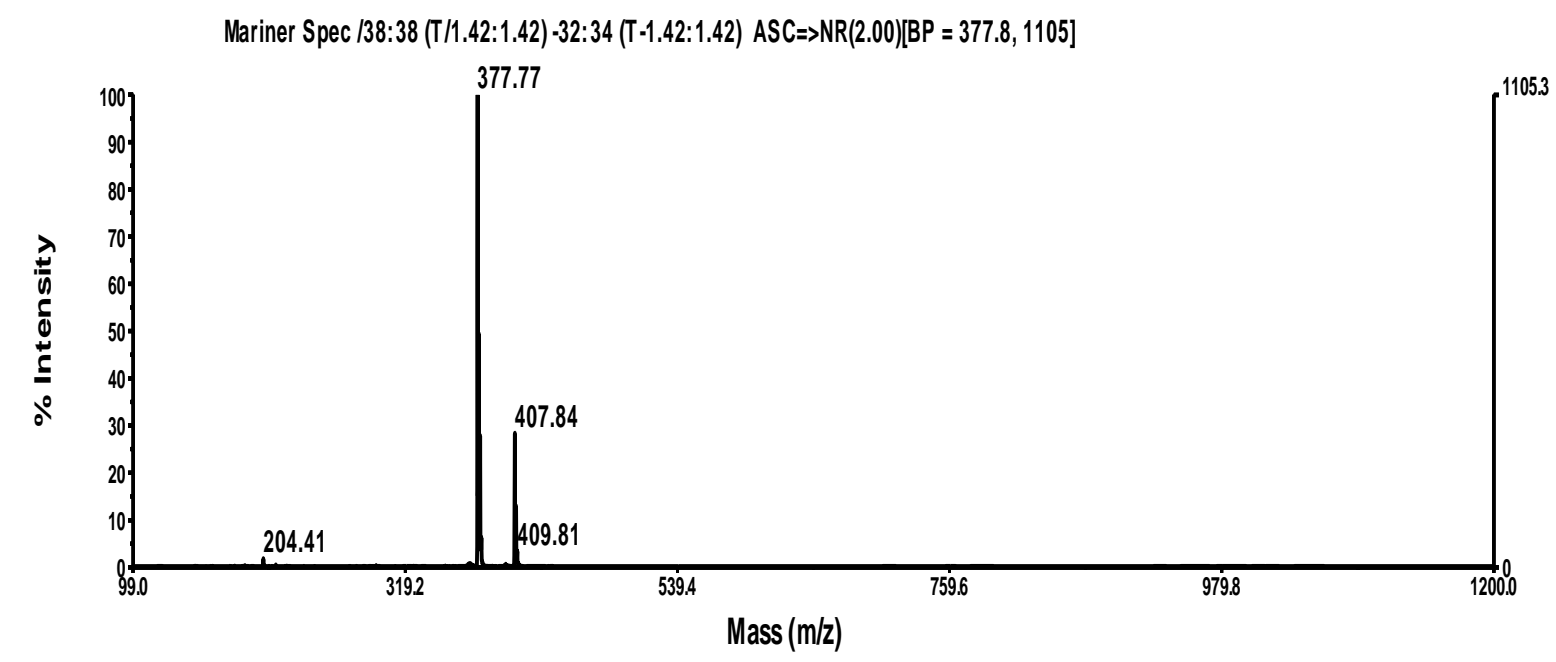

Fig. 3. The Spectrum of LC-ESI-MS

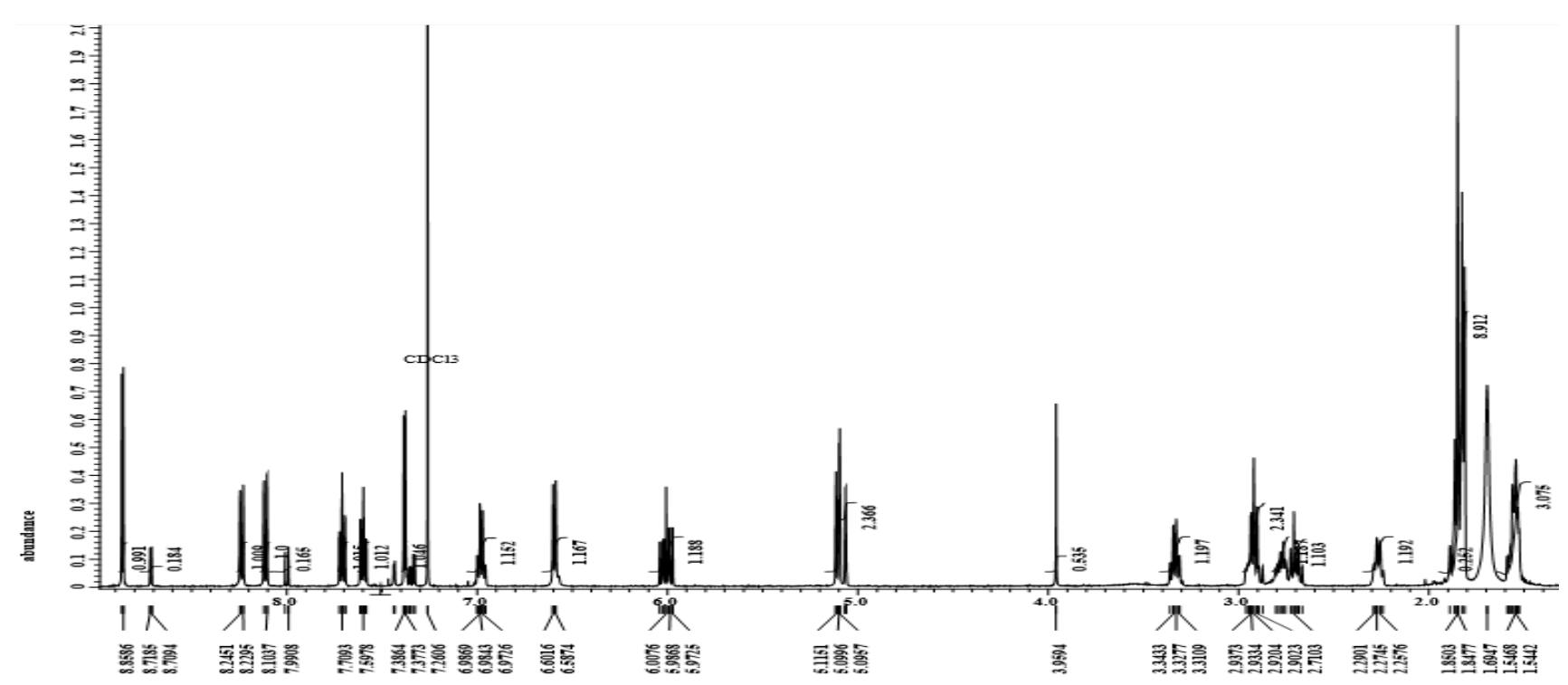

$\mathbf{x}$ : parts per Milition : $\mathbf{1 H}$

Fig. 4. ${ }^{1} \mathrm{H}-\mathrm{NMR}$ spectra of cinchonine tiglat 


\subsection{Structural identification using LC-ESI- MS and ${ }^{1}$ H-NMR}

The cinchonine tiglat was indentified using LC-ESI-MS with $\mathrm{MeOH}$ as the solvent and type $\mathrm{C}-18$ column $(15 \mathrm{~mm} \times 1 \mathrm{~mm})$. The spectral figures in Figure 3. shows that the compound had a retention time (tR) of 1,42 minutes and the molecule's peak ion $(\mathrm{m} / \mathrm{z})$ was at 377,77. Tiglic cinchonine has the molecular formula of $\mathrm{C}_{24} \mathrm{H}_{28} \mathrm{~N}_{2} \mathrm{O}_{2}$ and a molar mass of 376,22; as stated by ChemDraw application. A delta of 1 molecule from the spectrum was caused by an additional proton $\left[\mathrm{M}+\mathrm{H}^{+}\right]$.

The ${ }^{1} \mathrm{H}-\mathrm{NMR}$ spectrum of cinchonine tiglat can be divided into two separate areas. The first area was 5-8 ppm from the quinoline ring and the alkene bond. The second area was between 1-4 ppm for the quinuclidine ring. The ${ }^{1} \mathrm{H}-\mathrm{NMR}$ spectrum from the second area proved to be difficult to observe due to its high density. A chenical shift $\delta \mathrm{H} \quad 6,49$ ppm indicated the peak of $\mathrm{H}-9$ to have doublet multiplication. The $\mathrm{H}-9$ peak was more downfield compared to protons from other quinuclidine ring due to its direct bond with $\mathrm{O}$ from the ester functional group (-COO-) at position $\alpha$ and with $\mathrm{N}$ in position $\beta$; with both exhibiting electronegativity, resulting in the peak's shift towards the right side [23]. A thorough spectrum list was stated in Figure 4. : ${ }^{1} \mathrm{H}-\mathrm{NMR}\left(\mathrm{CDCl}_{3}\right): 8.86(1 \mathrm{H}, \mathrm{d}, 4.55 \mathrm{~Hz}, \mathrm{H}-$ 2'), $8.23\left(1 \mathrm{H}, \mathrm{d}, 7.8 \mathrm{~Hz}, \mathrm{H}-5^{\prime}\right), 8.11(1 \mathrm{H}, \mathrm{d}$, $7.8 \mathrm{~Hz}, \mathrm{H}-8$ '), $7.71\left(1 \mathrm{H}, \mathrm{dd}, 7.1 \mathrm{~Hz}, \mathrm{H}-7^{\prime}\right)$, $7.61(1 \mathrm{H}, \mathrm{dd}, 7.1 \mathrm{~Hz}, \mathrm{H}-6$ ') $7.37(1 \mathrm{H}, \mathrm{d}, 4.55$ Hz, H-3'), 6.98 (1H, q, 5.85 Hz, H-4'”), 6.60 $(1 \mathrm{H}, \mathrm{d}, 7.1 \mathrm{~Hz}, \mathrm{H}-9), 6.00$ (1H, m, H-10), 5.10 (2H, m, H-11), $3.34(1 \mathrm{H}, \mathrm{q}, 7.8 \mathrm{~Hz}, \mathrm{H}-8), 2.95$ (2H, m, H-6), 2.93 (1H, s, H-3"'), 2.72 (2H, m, H-2), 1.16 (3H, d, $5.14 \mathrm{~Hz}, \mathrm{H}-5$ '"), $2.69(1 \mathrm{H}$, $\mathrm{m}, \mathrm{H}-3), 1.86$ (2H, m, H-5), 1.81 (1H, m, H-4), $1.54(2 \mathrm{H}, \mathrm{m}, \mathrm{H}-7)$. Based on the results from LC-ESI-MS and ${ }^{1} \mathrm{H}-\mathrm{NMR}$, we concluded that the synthesis of cinchonine tiglat was successful.

\subsection{In vitro anticancer activity of cinchonine tiglat}

The cytotoxicity test was done in vitro to see if there were any anticancer potential against MCF-7 breast cancer cell's growth.
The first step of the test was filtering, followed by isolating the chemical compound which is responsible for the anticancer properties. This method does not explain the mechanism behind the anticancer properties. The test was employed to MCF-7 breast cancer cell using Alamar Blue method.

The Alamar Blue reagent contains resazurin; which exhibits bluish colour without fluorescence. This compound can be reduced into a fluorescent pink resorufin when meeting certain conditions. The change of colour from blue (resazurin) into pink (resorufin) indicated its reduction by cancerous cells [24]. The process of colouring cells with Alamar Blue needed 4 hours of incubation. The result of tigliccinchonine's test are as follows:

Table 1. Viability percentage of cinchonine tiglat

\begin{tabular}{cc}
\hline $\begin{array}{c}\text { Concentration } \\
(\mathbf{p p m})\end{array}$ & $\begin{array}{c}\text { Viability } \\
(\boldsymbol{\%})\end{array}$ \\
\hline 0,0391 & 127,11 \\
0,0781 & 111,61 \\
0,1563 & 96,06 \\
0,3125 & 80,54 \\
0,625 & 65,00 \\
1,25 & 49,47 \\
2,5 & 33,94 \\
5 & 18,40 \\
10 & 2.87 \\
20 & $-12,66$ \\
\hline
\end{tabular}

As shown by Table 1, the lower the concentration of cinchonine tiglat, the higher the rate of surviving cancerous cells (shown by the higher viability percentage). Dose dependency is a common trait among most anticancer compounds; the higher the concentration, the higher its ability to inhibit cancerous cells' growth.

The $\mathrm{IC}_{50}$ value (the minimum concentration of sample to exhibit the ability to inhibit $50 \%$ of the cancerous cells' growth) of tiglic cinchonine was $1,22 \mathrm{ppm}$ with correlation coefficient of 0,9000 from the regressive equation $\mathrm{y}=-51,60 \log \mathrm{X}+54,47$. The lower 
the $\mathrm{IC}_{50}$ value, the more efficient it is as anticancer agent.

As shown by its $\mathrm{IC}_{50}$ value; cinchonine tiglat exhibits a powerful anticancerous activity. Tiglic cinchonine is a derivative compound from cinchonine and tiglic acid. By it self, cinchonine is already a great candidate as multidrug resistance (MDR) agent. Cinchonine's activity as an MDR agent is relatively more powerful than most other chincona alkaloids; hence why it is a great addition to combine with other chemotherapy drugs [16].

Cinchonine tiglat's structure follows Lipinski's rule. Lipinski's rule was made to determine compound's physicochemical properties as well as whether the stated compound has a hydrophobic or hydrophyllic tendency to penetrate the cellular membrane through passive diffusion. Lipinski's rule stated that compounds with molecular mass of less than 500; will have a Log $\mathrm{P}$ value of less than 5, a number of hydrogen bond donor of less than 5 , and a number of hydrogen bond acceptor of less than 10 [25]. Based on ChemDraw, cinchonine tiglat structure has a Log P value of 4,23; molecular mass of 376,22 ; 0 amount of hydrogen bond donor; and 4 amount of hydrogen bond acceptor.

MCF-7 cell is a strand of breast cancer cell that has a tendency to be more resistant against chemotheray agents, especially when compared to T47D cell. This type of cell has been known to be resistant against Doxorubicin; a type of commonly used chemotherapy agent [26]. This is why finding a newer type of drug to combat the resistance is crucial.

The synthesization of cinchonine tiglat was done to increase cinchonine's lipophilicity to ultimately increase cinchonine's anticancerous ability [20]. Table 2 shows the $\mathrm{IC}_{50}$ value of tiglic cinchonine is $1,22 \mathrm{ppm}$; lower than that of cinchonine at 1,32 ppm. This meant an increase of cinchonine tiglat's anticancerous activity compared cinchonine. Cinchonine tiglat's anticancerous ability is in line with the used positive control variable; antimycin, but cinchonine tiglat exhibits a better $\mathrm{IC}_{50}$ value.
Table 2. Anticancer activity of cinchonine tiglat

\begin{tabular}{cc}
\hline Compounds & $\begin{array}{c}\text { MCF-7 } \\
\text { (IC } 5 \text { in } \mathbf{~ p p m})\end{array}$ \\
\hline Cinchonine & 1.32 \\
Cinchonine tiglat & 1.22 \\
Antimycin & 1.24 \\
\hline
\end{tabular}

\section{CONCLUSIONS}

Structurally, cinchonine tiglat follows Lipinski's rule. Cinchonine's anticancerous property was increased after having its lipophilicity increased. Cinchonine tiglat exhibits a high number of cytotoxic activity against MCF-7 breast cancer cells with $\mathrm{IC}_{50}$ value of $1,22 \mathrm{ppm}$.

\section{ACKNOWLEDGEMENT}

We thanks Chemical Science and Technological Institute of Indonesia (LIPI), Puspitek, Serpong for giving us a chance to finish this study. We also appreciated PT. Sinkona Indonesia Lestari (PT. SIL) for providing Chincona Alkaloids.

\section{REFERENCES}

[1]. Ferlay J, Soerjomataram I, Ervik M, et al; International Agency for Research on Cancer. GLOBOCAN 2012 v1.0, Cancer Incidence and Mortality Worldwide: IARC CancerBase No. 11. globocan.iarc.fr. Accessed December 12, 2013

[2]. Lindsey A. Torre, MSPH1 ; Freddie Bray, PhD2 ; Rebecca L. Siegel, MPH3 ; Jacques Ferlay, ME4 ; Joannie LortetTieulent, MSc5 ; Ahmedin Jemal, DVM, Ph D2015 Global Cancer Statistics, 2012 CA: A Cancer Journal for Clinicians 2015;65:87-108

DOI: $10.3322 /$ caac. 21262

[3]. Kundu, C.N., Satria D., Anmada N., Shakti, R.S., Dipon D., \& Sumit S. (2015). Review: Anti-malarials are anticancers and vice versa - One arrow two sparrows. Acta Tropica, 149, 113-127. 
http://doi.org/10.1016/j.actatropica.2015. $\underline{03.028}$

[4]. Krishnaveni, M., and Kathiresan S., 2015, A Study on Protective Effect of Quinine against Lipid Peroxidation and Antioxidants Status in Human Oral Cancer Cell Line, Research Journal of Pharmaceutical, Biological and Chemical Sciences, vol. 6 (5), hlm 295231, ISSN: 0975-8585

[5]. Károlyi, B.I., Bősze, S., Orbán, E., Sohár, P., Drahos, L., Gál, E., and Csámpai, A., 2012, Acylated mono-, bisand tris- Cinchona-Based Amines Containing Ferrocene or Organic Residues: Synthesis, Structure and in Vitro Antitumor Activity on Selected Human Cancer Cell Lines, journal molecules, vol. 17, hal. 2316-2329, ISSN 1420-3049, doi:10.3390/molecules17032316

[6]. Preet, R., Mohapatra, M., Mohanty, S., Sahu, S.K., Choundhuri, T., Wyatt, M.D., and kundu, C.N., 2012, Qunacrine has anticancer activity in breast cancer cells through inhibition of topoisomerase activity, Int. J. cancer, vol. 130, 16601670.

[7]. Wu, D. 2003. Studies on novel heterocyclic compounds and their microbicidal efficacy. Tetrahedron. 59, 8649-8687

[8]. Mfan, S., Anand, K., Anandakumar, S., Singh, S., Chuturgoon, A. A., \& Gengan, R. M. (2016). Discipline of Medical Biochemistry , School of Laboratory Medicine and Medical Sciences ,. JPB. http://doi.org/10.1016/j.jphotobiol.2016. $\underline{10.009}$

[9]. Achan, J., Talisuna, A.O., Erhart, A., Yeka, A., Tibenderana, J.K., Baliraine, F.N., Rosen-thal, P.J., D'Alessandro, U., 2011. Quinine, an old anti-malarial drug in a modernworld: role in the treatment of malaria. Malar. J. 10, 144.

[10]. Schlesinger, P.H., Krogstad, D.J., Herwaldt, B.I., 1988. Antimalarial agents: mecha-nisms of action.
Antimicrob. Agents Chemother. 32, 793-798.

[11]. Mohapatra, P., Preet, R., Das, D., Satapathy, S.R., Choudhuri, T., Wyatt, M.D., Kundu,C.N., 2012. Quinacrinemediated autophagy and apoptosis in colon cancer cellsis through a p53- and p21-dependent mechanism. Oncol. Res. 20, 81-91.

[12]. Genne, P., Duchamp P., Solary E., Pinard D., Belon J.P., Dimanche Boitrel M.T., Chauffert B., 1994, Comparative effects of quinine and cinchonine in reversing multidrug resistance on human leukemic cell line K562/ADM, Leukemia, 8: 160-164.

[13]. Furusawa, S., Nakano, S., Wu, J., Sakaguchi, S., Takayanagi, M., Sasaki, K., and Satoh, S., 2001, Apoptosis induced by doxorubicin and cinchonine in P388 multidrug-resistant cells, Journal of Pharmacy and Pharmacology, 53: 1029-1039.

[14]. Lee, S., Rhee, Y., Jeong, S., Lee, H., Jung, M., Kim, S., Lee, E., Ahn, K.S., Kim, S.H., 2009, Hydrocinchonine, Cinchonine, and Quinidine Potentiate Paclitaxel-Induced Cytotoxicity and Apoptosis via Multidrug Resistance Reversal in MES-SA/DX5 Uterine Sarcoma Cells, Environmental Toxicology, 26: 424-431

[15]. Genne, P., Dimanche-Boitrel M.T., Mauvernay R.Y., Gutierrez G., Duchamp O., Petit J.M., Martin F., Chauffert B., 1992, Cinchonine, a potent efflux inhibitor to circumvent anthracycline resistance in vitro and in vivo, Cancer Res, 52: 2797-2801.

[16]. Genne, P., Duchamp P., Solary E., Magnette J., Belon J.P., Chauffert B., 1995, Cinchonine per os: efficient circumvention of Pglycoproteinmediated multidrug resistance, Anti-Cancer Drug Design, 10: 103-118. 
[17]. Lehnert, M., 1998, Chemotherapy resistance in breast cancer, Anticancer Res, 18: 2225-2226

[18]. Beaumont, K., Webster, R., Gardner, I. \& Dack, K. Design of ester prodrugs to enhance oral absorption of poorly permeable compounds: challenges to the discovery scientist. Curr. Drug Metab. 4, 461-485 (2003).

[19]. Sanda, \& Radu, R. (2012). Contribution to cinchona alkaloids chemistry, 1-46.

[20]. Kumura, N., Izumi, M., Jima, S. N., Shimizu, S., Kim, S., Wataya, Y., Baba, N. B. (2005). Synthesis and Biological Activity of Fatty Acid Derivatives of Quinine, Biosci, Biotechnol, Biochem, $69 \quad$ (11), 2250-2253. http://doi.org/10.1271/bbb.69.2250

[21]. Mario, Puspa D.N.L., Gian P., Sylvia R.P., and Muhammad H. 2017. Synthesis and cytotoxicity assay using Brine Shrimp Lethality Test of Cinchonidine Isobutyrate Ester. Indonesian Journal of Applied Chemistry. 19(1), 29-35, e-ISSN:25277669 .

[22]. M V Lancaster, R D Fields. 1996, Antibiotic and cytotoxic drug susceptibility assays using resazurin and poising agents, U.S Patent, 5501959 A

[23]. Fessenden, R.J., \& Fessenden, J.S. 1991. Kimia Organik Edisi III jilid I (III). Massachuset: Penerbit Erlangga.

[24]. Page, A.B., Page, A.M., and Noel, C., 1993, A new fluorimetric assay for cytotoxicity measurements in vitro, Int. J. Oncol, 3, 473-476

[25]. Lipinski, C.A., Lombardo, F., Dominy, B.W., \& Feeney, P.J., 1997, Experimental and computational approaches to estimate solubility and permeability in drug discovery and development settings, Advanced Drug

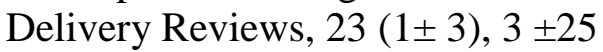

[26]. Zampieri, L., Bianchi, P., Ruff, P., and Arbuthnot, P., 2002, Differential Modulation by Estradiol of P- glycoprotein Drug Resistance Protein Expression in Cultured MCF7 and T47D Breast Cancer Cells, Anticancer Res., 22, 2253-2259 